\title{
Burned Rock Mounds in North-Central and Northeastern Oklahoma
}

Robert L. Brooks

Unknown

Follow this and additional works at: https://scholarworks.sfasu.edu/ita

Part of the American Material Culture Commons, Archaeological Anthropology Commons, Environmental Studies Commons, Other American Studies Commons, Other Arts and Humanities Commons, Other History of Art, Architecture, and Archaeology Commons, and the United States History Commons

Tell us how this article helped you.

This Article is brought to you for free and open access by the Center for Regional Heritage Research at SFA ScholarWorks. It has been accepted for inclusion in Index of Texas Archaeology: Open Access Gray Literature from the Lone Star State by an authorized editor of SFA ScholarWorks. For more information, please contact cdsscholarworks@sfasu.edu. 


\section{Burned Rock Mounds in North-Central and Northeastern Oklahoma \\ Creative Commons License \\ (c) $($ ) $(9)$}

This work is licensed under a Creative Commons Attribution-NonCommercial 4.0 International License 


\title{
BURNED Rock MOUNDS In NORTH-CENTRAL AND NORTHEASTERN OKLAHOMA
}

\section{Robert L. Brooks}

\begin{abstract}
Burned rock mounds have been identified in Oklahoma since the early twentieth century. The Oklahoma River Basin Survey pioneered the study of these features of the cultural landscape in the 1960s-1970s; however, little research has taken place since that time. This paper reports on the history of research pertaining to burned rock mound features, examines their distribution on the cultural landscape and their construction, analyzes the artifact content of the mounds, and presents some thoughts on the purpose of mound construction and use.
\end{abstract}

\section{Introduction}

Burned rock mounds are a distinctive feature for the prehistoric cultural landscapes of north-central and northeastern Oklahoma (Figure 1). Significant volumes of burned rock are present as slightly mounded circumscribed areas on the natural landscape. Typically, these features are oval to round in shape and cover an area that averages approximately 20 meters in diameter. The mounded effect from the loading of burned rock creates a slight rise on the natural landscape, generally less than a meter in height. Burned rock mounds present in wooded areas would be would prove difficult to identify. To the casual observer, the mound illustrated in Figure 2 might be perceived as naturally occurring and not receive further attention. But, these are constructed features of the cultural landscape.

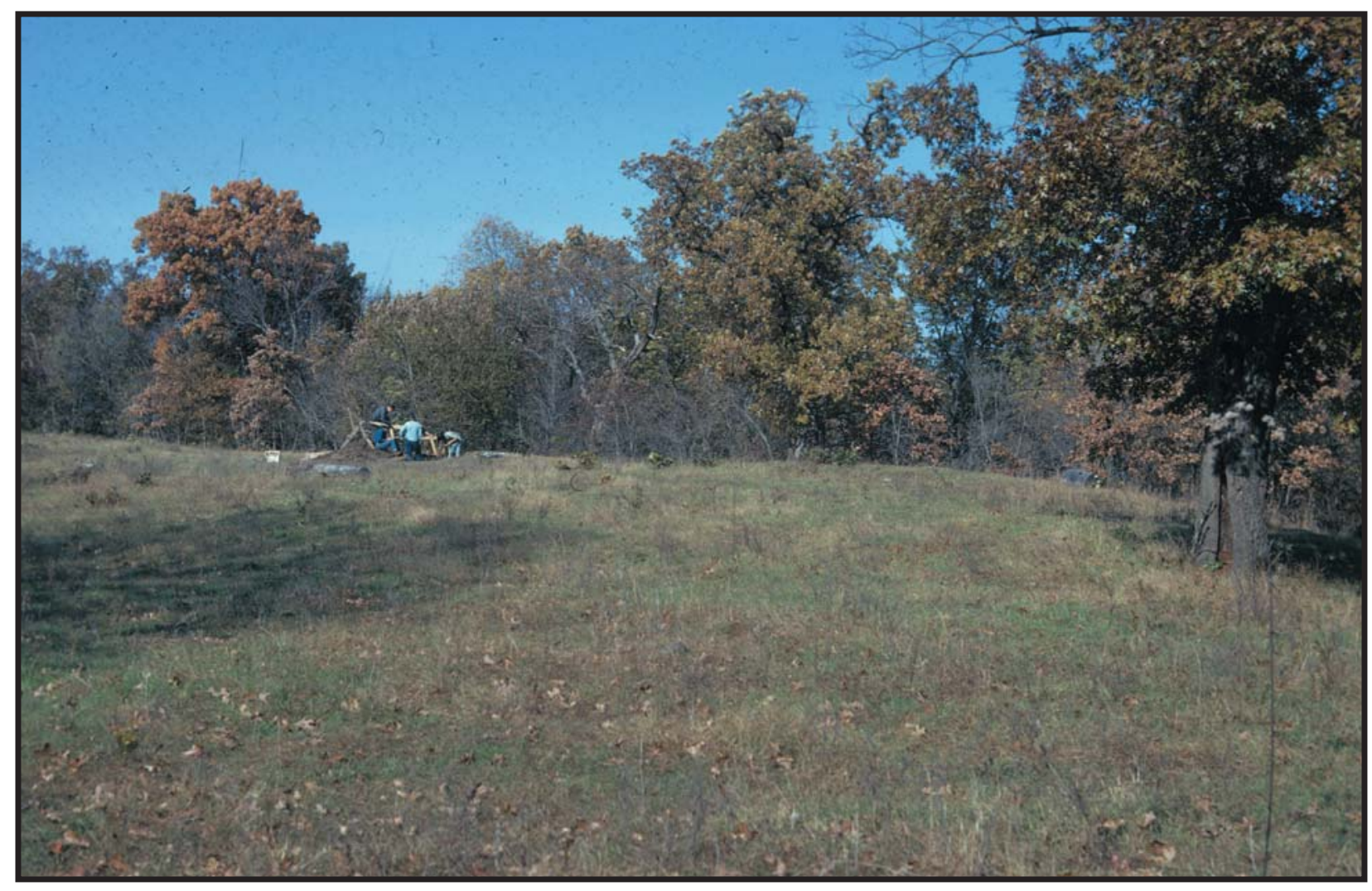

Figure 1. D Bar D burned rock mound (34WN65) illustrating slight rise on natural landscape (main mound is to right of excavations.) 


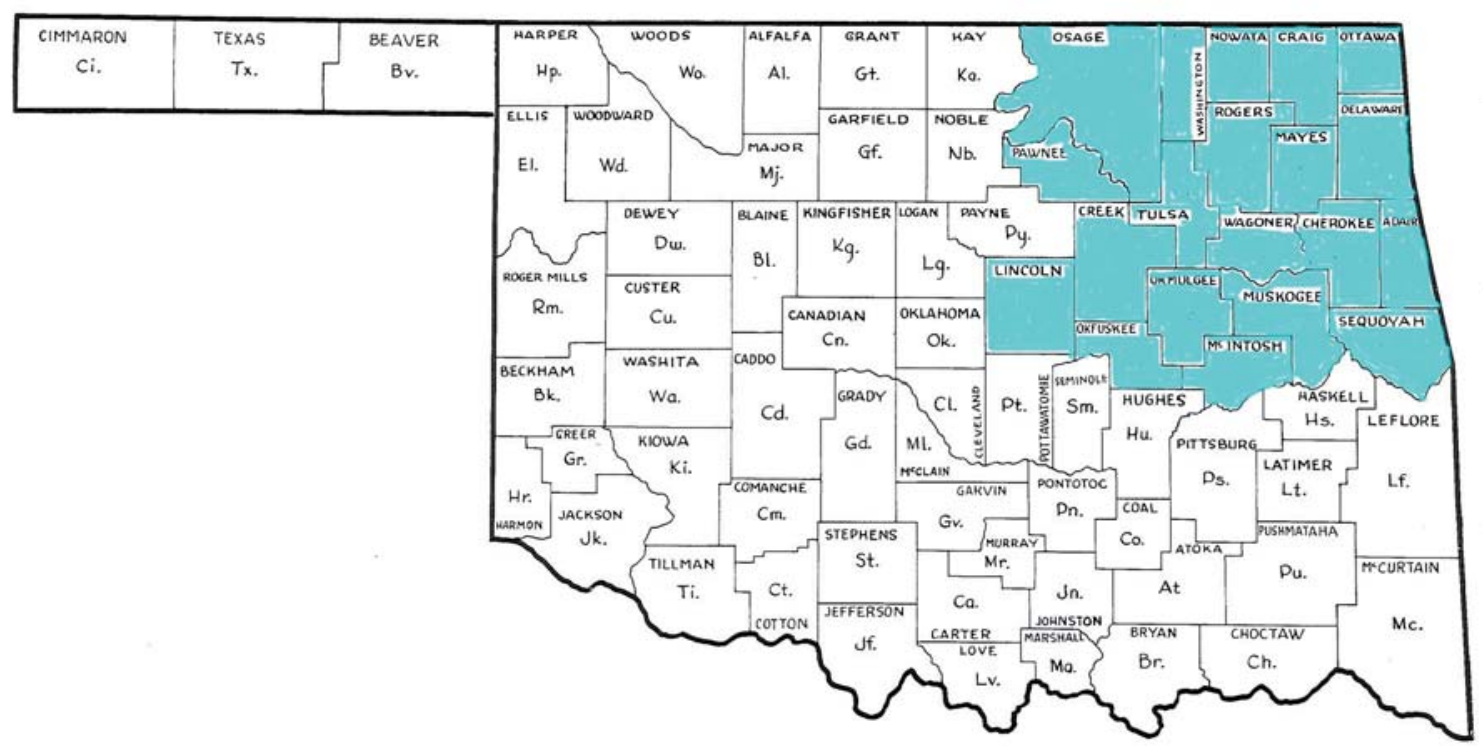

Figure 2. Occurrence of burned rock ounds in northicentral and northeastern Oklahoma.

These features of the built environment are also frequently confused with naturally occurring prairie or mima mounds that occur within the same geographic area (Allgood and Gray 1974; Branson 1966; Cain 1974). Prairie or mima mounds present a similar surface expression of a slightly mounded, circumscribed area. The principal difference is in the mound content. Prairie mounds exhibit a natural sequence of soil development with no evidence of culturally derived construction, especially the large volume of burned rock. However, prehistoric groups sometimes resided on prairie mounds, leaving behind debris that masks the natural origin of the mounded surface, complicate the identification of natural mounds. In other instances, hearths are prepared and used on naturally occurring mound surfaces. Prehistoric societies have further added to the confusion by constructing their rock mound features amid naturally occurring prairie mounds (which they also used). Thus, caution needs to be exercised in defining burned rock mound features and sites.

One other noteworthy introductory point should be made concerning the burned rock mounds of northcentral and northeastern Oklahoma. They do not represent burial cairns or burial mounds. Burial cairns and burned rock mounds with burials are found in southeastern Kansas and southwestern Missouri (cf., Hawley 2003; Jones 1999; Williams 1988; Chapman 1980). These mounds are frequently constructed of stone slabs or irregularly shaped stone and hold burned/unburned human bone; they reflect a specialized mortuary practice for these areas. To date, none of the investigated burned rock mounds in Oklahoma have yielded human remains or evidence to suggest that they were part of a prepared burial ritual. There is one mound in Osage County that contains burned rock and also burials (34OS99; Howard 1970). However, there are significant differences in the construction of this mound compared to the burned rock mounds addressed in this analysis. The mound excavated by Howard also dates to the late prehistoric period whereas the burned rock mound features discussed here are somewhat earlier, dating to the Woodland period.

Following sections of this paper present the history of burned rock mound research; discuss the distribution and characteristics of burned rock mounds; the chronology and cultural affiliation of the mounds; and function of the mounds as derived from analysis of mound content. Final comments examine the purpose of burned rock mounds within the practices of prehistoric societies of north-central and northeastern Oklahoma. 


\section{History of Burnt Rock Mound Research}

Joseph Thoburn appears to be the first researcher to mention rock mounds (Thoburn 1931). Thoburn also recognized that some of the slightly mounded expressions on the land were natural features rather than cultural ones. However, his work generated considerable confusion as he often failed to clarify in his writing whether he was detailing characteristics of earthen mounds (which he excavated in McIntosh, Delaware, and Le Flore counties), burned rock mounds, or the natural prairie mounds that prehistoric people had occupied. In many of his studies, he describes these mounds as "earth lodges", although as revealed in Thoburn's discussion of work at the Ward Mounds at Spiro (Thoburn 1931: 64), this term should be reserved for his discussion of built earthen mounds.

Despite Thoburn's earlier recognition of rock mounds and their own work at the black midden mounds of the Wister Valley, WPA-era archaeologists did not identify burned rock mounds during their investigations in eastern Oklahoma. This is also true of the early surveys conducted for proposed lakes in eastern Oklahoma (Keystone, Tenkiller, Eufaula, and Fort Gibson) sponsored by the Department of Anthropology at the University of Oklahoma (Brighton 1952; Wenner 1947a, 1947b, and 1948).

The first extensive documentation and study of burned rock mounds took place during Oklahoma River Basin Survey and later investigations throughout northeastern Oklahoma in the 1960s and 1970s. Survey of the Markham Ferry Reservoir in the early 1960s resulted in the identification of 10 burned rock mound sites (Wyckoff, Robison, and Barr 1963; Wyckoff and Barr 1964; Barr 1966). Multiple mounds at four of these sites were ultimately excavated: Packard Mound (34MY69), Bell (34MY78), Sparks Mound (34MY88), and Satterfield Mounds (34MY91).

A study of the Arkansas River Navigation System (Barr 1965) and Webbers Falls Lock and Dam (Schneider 1967) in Wagoner and Muskogee counties resulted in the documentation of nine sites exhibiting burned rock mound features. Schneider (1967) subsequently tested the Bogus Mounds (34WG18) and Wendtland Mounds. This work revealed the Wendtland Mounds to be natural features, thus providing archaeological evidence for the distinction between built and naturally occurring mounds. A few sites with burned rock mounds were also identified during surveys of Oologah Reservoir in Nowata and Rogers counties (Prewitt 1968; Nichols et al. 1980) and Skiatook Reservoir in Osage County (Perino 1972).

The most extensive study of burned rock mounds was carried out during the Copan Lake Project. Twenty-five sites containing multiple burned rock mounds were identified during the initial survey and subsequent investigations (Rohn and Smith 1972; Vaughn 1975; and Vehik and Pailes 1979). Multiple mounds at eight of the burned rock mound sites were subsequently investigated (34WN2, 34WN38, 34WN41, 34WN45, 34WN55, 34WN65, 34WN73, and 34WN82). As in the case of work at Markham Ferry Reservoir, human constructed mounds were frequently interspersed with naturally occurring prairie mounds and provided archaeologists further opportunities to distinguish between these cultural and natural landscape features. Data derived from work by Vaughn (1975) and Vehik and Pailes (1979) provided additional details on the construction of the burned rock features as well as mound content.

Since the 1970s there has been less attention devoted to burned rock mound features. The most substantial work took place at two burned rock mounds in Okfuskee County (34OF38 and 34OF39) initially recorded during a survey of Impoundment B-2 in the Okfuskee County Tributaries Watershed (Wallis 1979). Excavations at these two sites by Rain Vehik (1980) represent the most extensive investigations of burned rock mounds since those undertaken at the previously discussed Copan Reservoir. Three sites with burned rock mound features were also documented during a survey of the Bird Creek Basin in Rogers, Tulsa, and Osage counties (Drass 1985) and the Upper Pryor Creek watershed in Nowata County (Harden 1977). During the past 20 years, there have a been a few additional burned rock mounds recorded as a result of work associated with federally funded or permitted activities (c.f., Henry 2008a, 2008b). 


\section{Distribution and Presentation on the Landscape}

There are approximately 100 sites scattered across 13 counties that contain some 264 burned rock mound features. However, these numbers represent approximations. As noted in the introduction, burned rock mounds are rather ephemeral expressions on the landscape and may go undetected even by archaeologists. Additionally, much of northeastern Oklahoma was cleared for cultivation in the late nineteenth and early twentieth centuries; this also contributed to the leveling of many burned rock mounds. These leveled mounds exist in the site files today as broadly disbursed scatters of burned rock. It is also difficult to accurately count the number of burned rock mound features at a given site due to their being constructed amid naturally occurring prairie mounds. For example, investigations at sites with multiple mound features in Copan Reservoir found some of the mounds to be constructed whereas others were natural occurring mounds (Vaughn 1975; Vehik and Pailes 1979). The Wendtland mounds excavated by Schneider (1967) in Wagoner County were also found to be prairie mounds. There are undoubtedly more burned rock mound features than currently recorded in the archaeological site files. But, it is also likely that at least some of the mounds thought to be constructed, are in fact, features of the natural landscape.

Burned rock mounds are also not randomly distributed on the natural landscape. They tend to be found along major streams and rivers (Figure 3). However, these features are not typically found on the stream terraces but on higher terraces or dissected uplands/bluffs that parallel the valley systems. A number of burned rock mounds were recorded by avocational archaeologists or by professionals who were working without detailed maps. This has impeded a full characterization of the placement of these sites within specific eco-regions or habitat types. However, it appears that many of the burned rock mound sites are found on the Cherokee Prairie or upland prairies of the Springfield and Ozark plateaus. This has led archaeologists studying the mounds to associate them with an upland prairie adaptation (e.g., Vehik and Pailes 1979).

There appears to be some clustering to the distribution of burned rock mounds as presented in the ARCGIS derived view (Figure 3). But, this may be a function of survey bias in earlier studies, particularly those of the Oklahoma River Basin, where comprehensive survey of the reservoirs could not be undertaken due to time and budget considerations.

As noted earlier, some sites contain multiple burned rock mound features. While some of the mounds at multiple mound sites may be naturally occurring features, previous research also documented the occurrence of multiple built mounds at numerous sites (c.f., Vaughn 1975 and Wyckoff and Barr 1964). The number of burned rock mound features per site was calculated, with the realization that the frequency would be disproportionally skewed in favor of multiple mound sites. Despite this skewing effect, 60 percent of the sites contain only a single burned rock mound feature. Twenty percent contain two to four mounds, roughly 12 percent hold five to nine mounds, and five percent have greater than 10 burned rock mound features (Figure 4). The sites containing greater than 10 burned rock mounds should be viewed with some skepticism although professional archaeologists reported most of these. It is unclear whether the presence of numerous burned rock mounds at a site reflects contemporaneous use of multiple features or that the mounds represent repeated sequences of use at the site locale. 


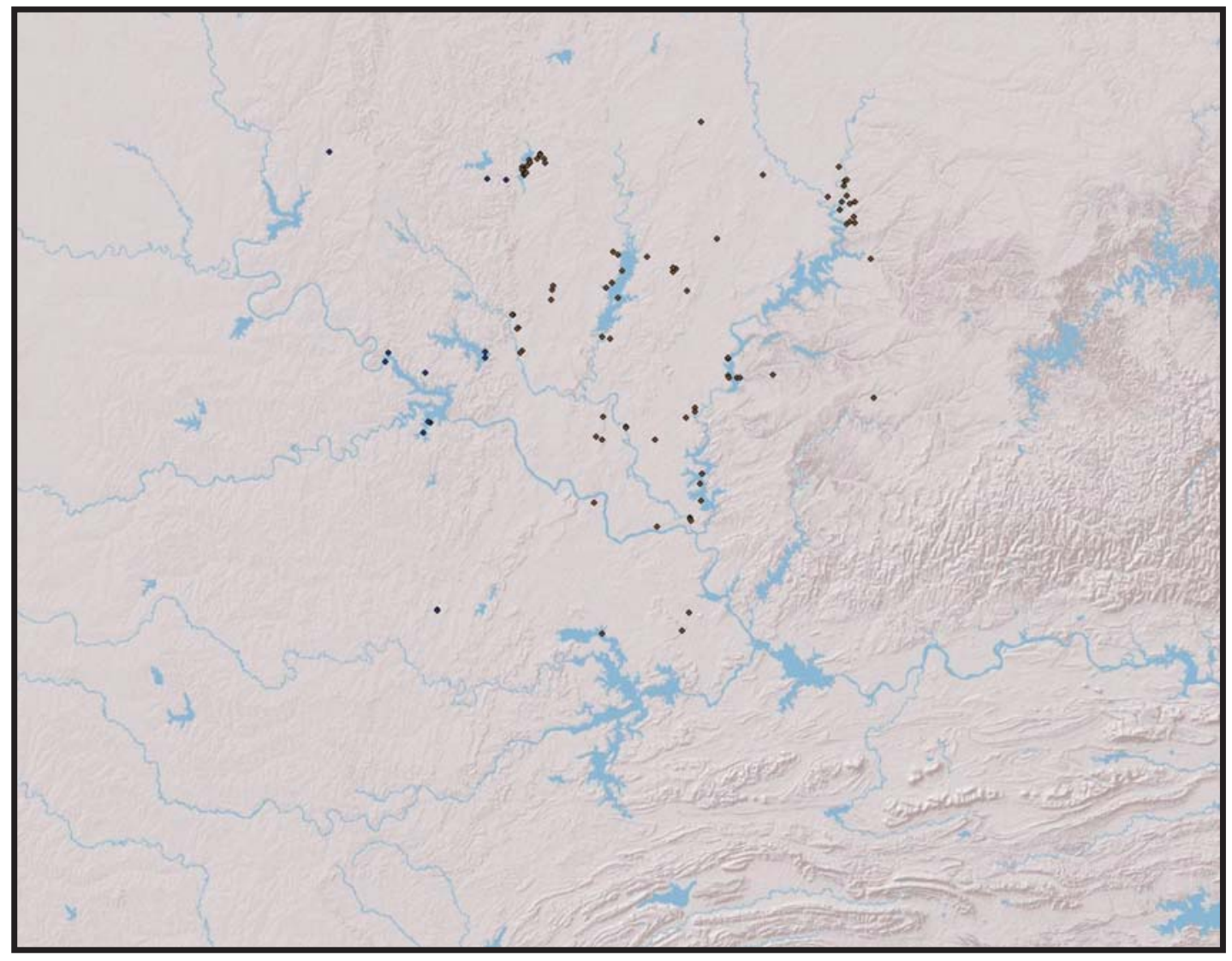

Figure 3. ARCGIS view of distrubution for burned rock mound sites in north-central and northestern Oklahaoma. Clusters may reflect aggreof burned rock mounds or simply reflect areas receiving greater research attention.

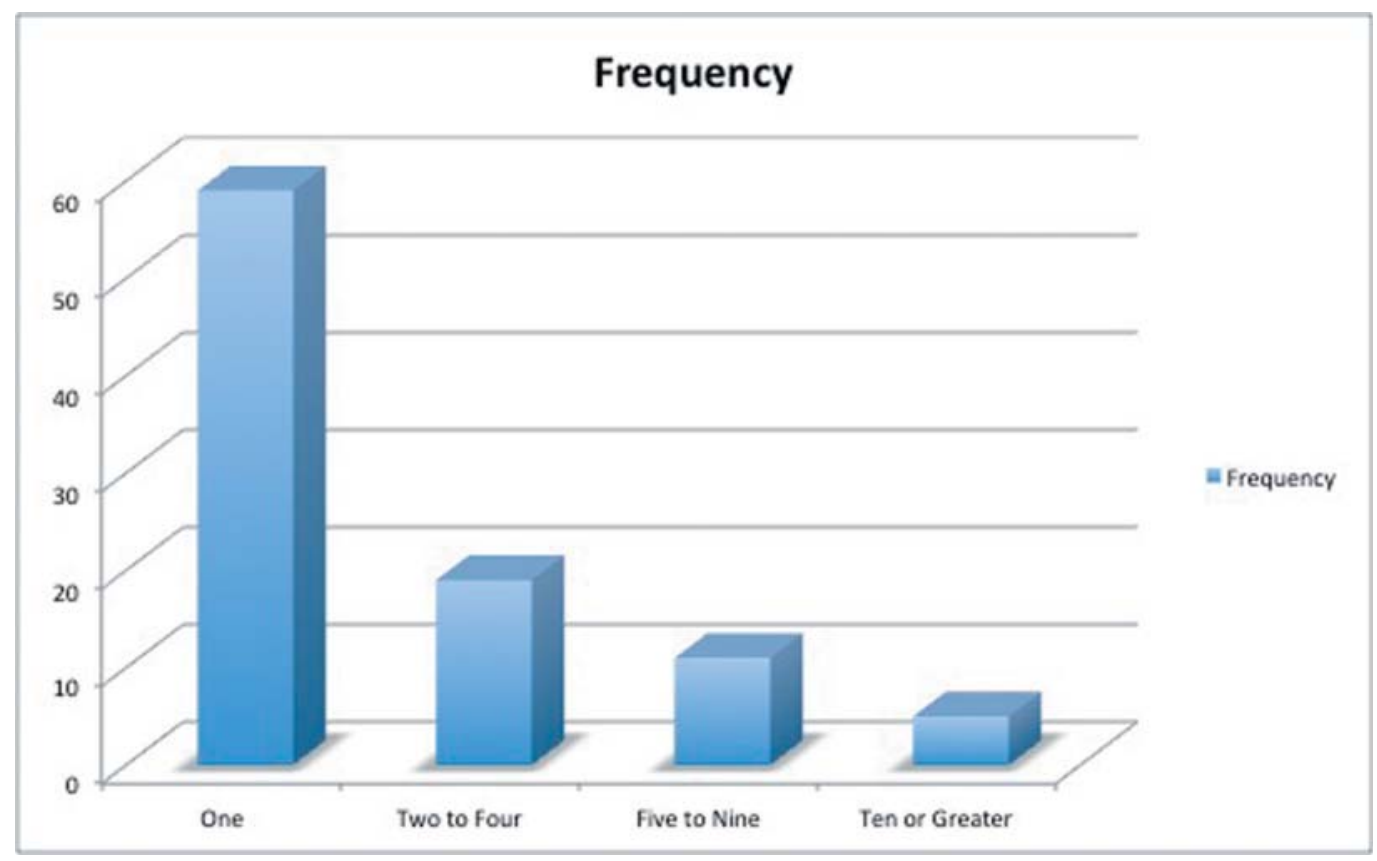

Figure 4. Histogram of number of burned rock mound features per site. 
The dimensions of burned rock mounds in respect to diameter and height were also examined. It was initially assumed that a larger mound footprint might result in greater mound height. Alternatively, a larger circumscribed area might result in a less mantled surface (based on the assumption that mounds spread over a greater surface area might result in some deflation in height). Conversely, a smaller footprint could also result in a more elevated surface area. However, a regression analysis of height and diameter demonstrated no linear relationship (Figure 5). There are undoubtedly factors that influenced mound dimensions at the time of construction and also modern events that contributed to mound height and diameter (e.g., land clearing, cultivation, etc.). Or, a combination of prehistoric events and modern circumstances may be responsible for current dimensions of burned rock mounds.

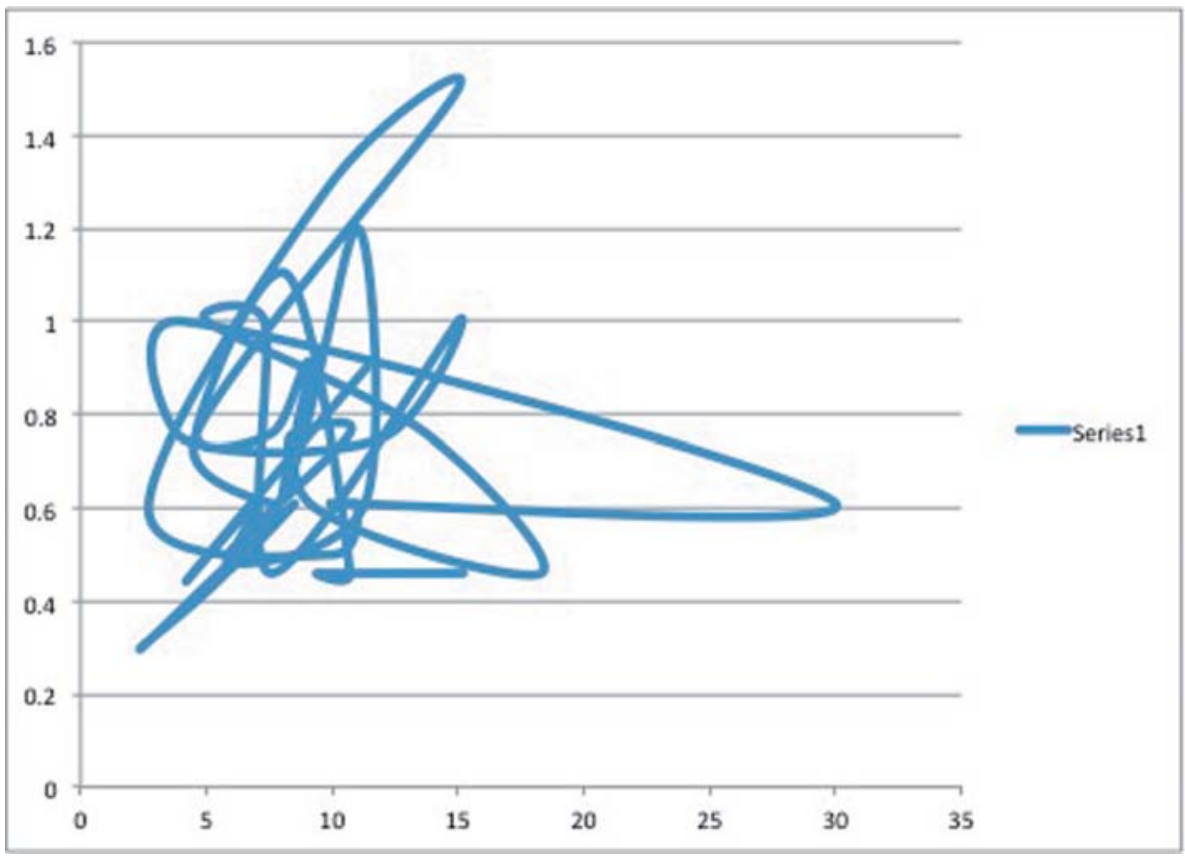

Figure 4. Histogram of number of burned rock mound features per site.

\section{Construction of Burned Rock Mounds}

Archaeologists have fairly good insights into the process of burned rock mound construction. This information comes from excavations at the Satterfield Mounds and Sparks Mounds (34MY91 and 34MY88; Wyckoff and Barr 1964), D Bar D Mounds (34WN65; Vaughn 1975), and Copperhead Mounds (34WN45; Vehik and Pailes 1979). Prehistoric inhabitants sometimes excavated the base of the mound to below ground surface. This is expressed not as a pit-like area but more as a shallow depression. Regardless of whether there is a sub-surface depression, the next phase involves the excavation of a hearth that is often centrally placed within the mound (Figures 6 and 7). In a few cases such as that at Mound 6 at the Copperhead Mounds and Mound A at the Satterfield Mounds, there are multiple hearths that may have been centrally located at the time of their use (or not!). The hearths are typically some two meters in diameter and range from 30 to $60 \mathrm{~cm}$ in depth. They may also extend below the depth of the shallow sub-surface of the mound. At the base/surface of the mound, there is sometimes a layer of gravel or chert clasts. It is unclear whether the hearth is dug through this layer or the gravels are distributed around the hearth (or perhaps both situations may exist). Archaeologists not familiar with the process of burned rock mound construction have argued that these gravel layers attest to the mounds' natural origin. However, Vaughn (1975) has convincingly demonstrated in the case of Mound D at the D Bar D mounds (34WN65) that stream gravels were transported to an upland bluff location where they were intentionally placed as the base layer in the mound. Following use and subsequent abandonment of the hearth, the 
hearth and surrounding surface area is buried under large quantities of burned rock. Regrettably, none of the studies attempted to quantify the volume of burned rock present at most mounds. However, from photos of mound profiles, such as that from Mound 7,34WN38, sizeable quantities of stone are involved (Figure 8). It is also clear from the mantling of the rock that this is a designed effort rather than the random discard of burned rock refuse. As Wyckoff and Barr (1964) and Vehik and Pailes (1979) have observed, large quantities of burned rock are usually associated with earth ovens. But, it is questionable whether the hearths found in the mounds are of sufficient size and duration of use to generate the impressive loads of burned sandstone and limestone present as mantling on the mounds. There has been only limited work in examining off-mound areas to determine whether there are earth oven/cooking pits present. At Mound 3 of the D Bar D Mounds, large bedrock slabs are present, creating a level surface that the hearth has penetrated. Burned rock is mantled over the slabs (Figure 9). The function of this floor-like area is unknown. However, it is intriguing that a similar stone slab surface is present on the earthen Mound D at the Harlan site, an early Caddoan ceremonial center. But, in the case of the Harlan site, the stone has been transported to the house mound and incorporated into mound construction rather than naturally occurring at the mound location.

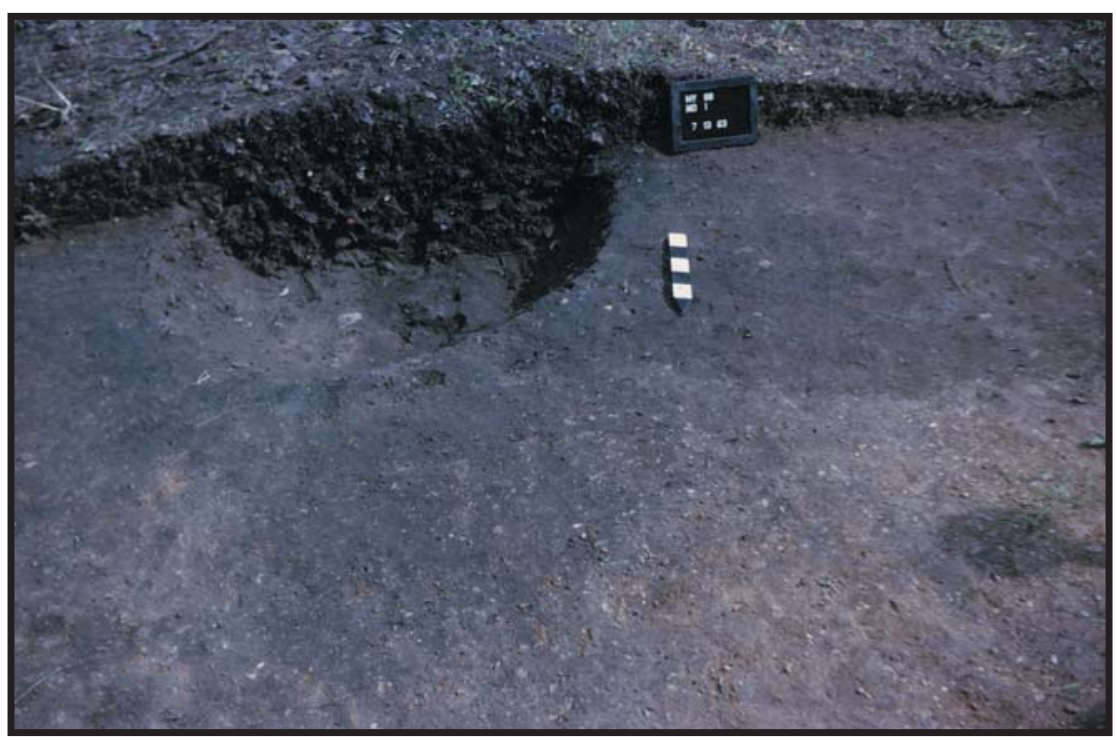

Figure 6. Centrally located hearth at the Sparks Mound (34MY88).

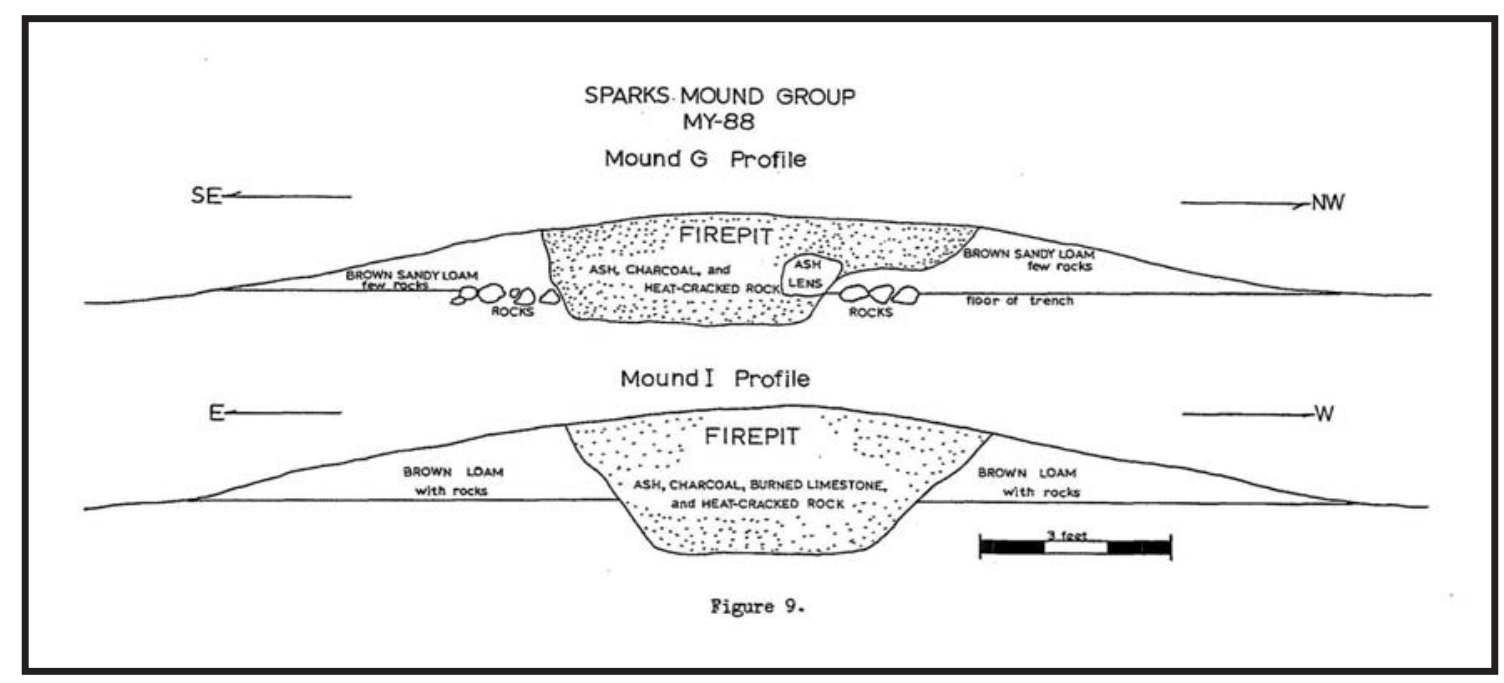

Figure 7. Profile of hearth, Sparks Mounds (34MY88). 


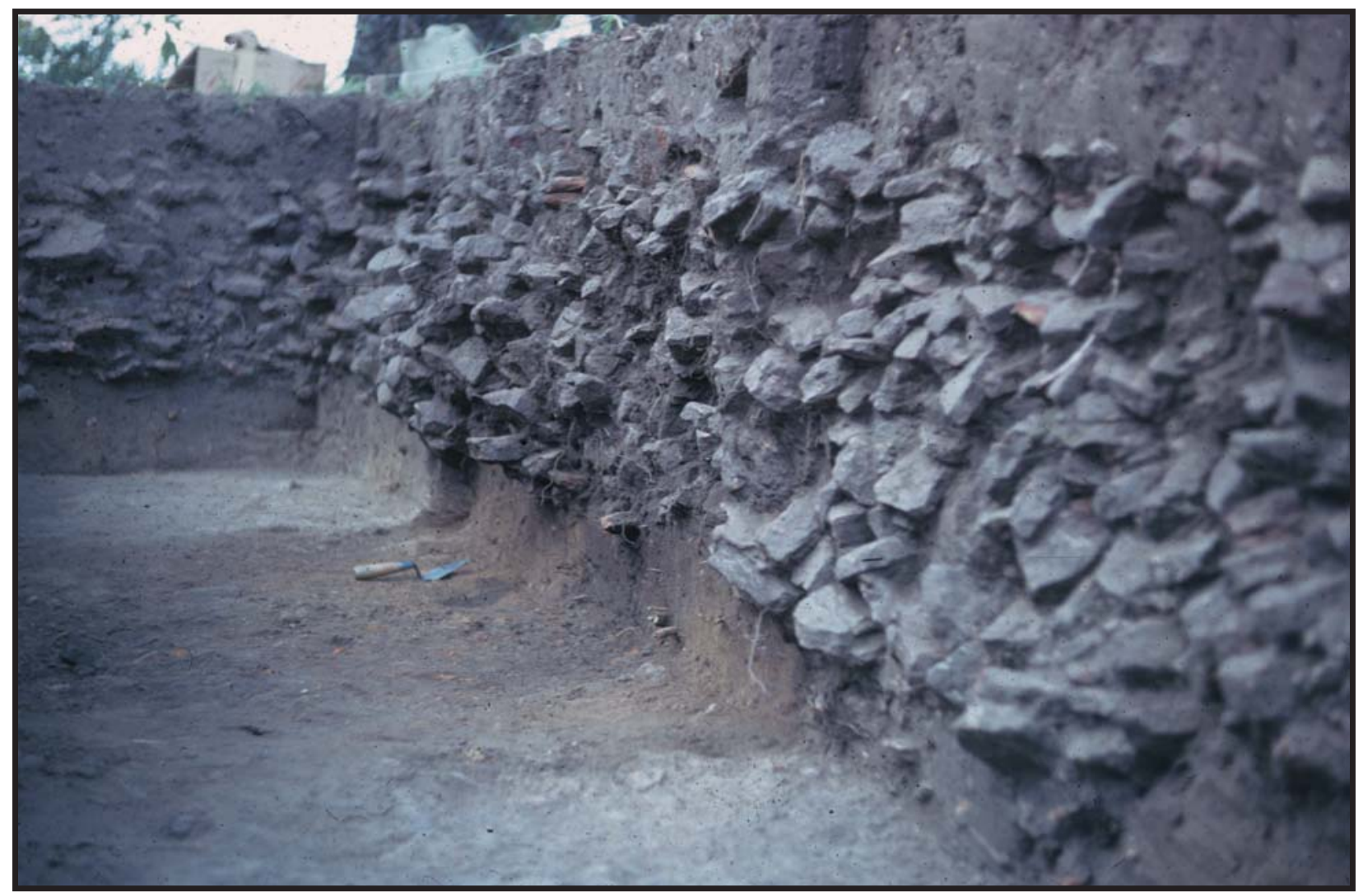

Figure 8. Burned rock mantle at Mound 7, Quail Patch site (34WN38), Copan Reservoir.

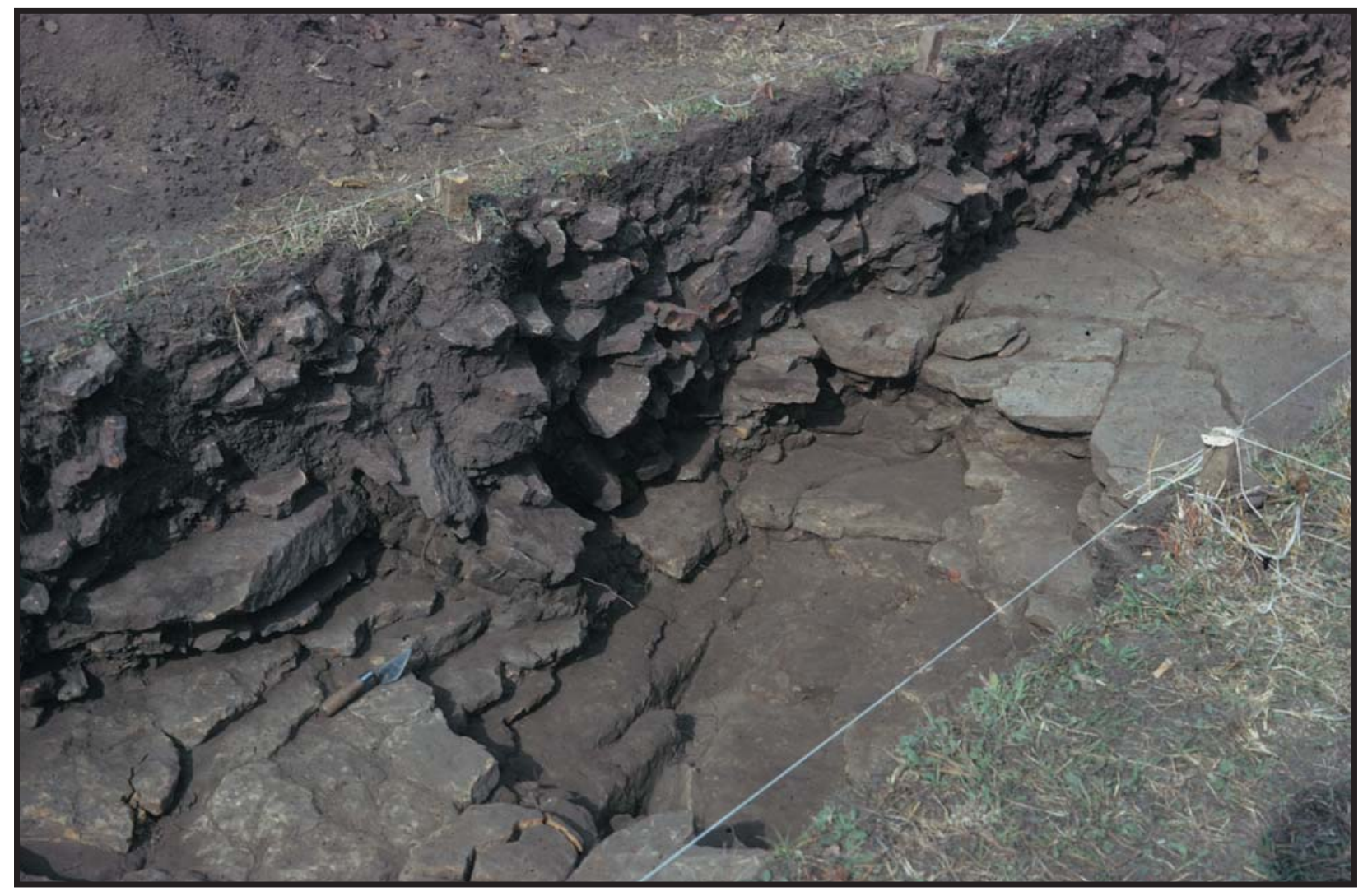

Figure 9. Burned rock mantled over bedrock slab surface of Mound 3, D Bar D Mounds (34WN65), Copan Reservoir. 


\section{Age and Cultural Affiliation of Burned Rock Mounds}

Despite the presence of hearths at a number of burned rock mounds, many of these do not contain sufficient quantities of charcoal for dating the time of mound use. This is true for other portions of the mounds as well. There are three valid radiocarbon dates from earlier work. Wyckoff's work (Wyckoff, Robinson, and Barr 1963) at the Packard Mounds (34MY69) yielded a date of $1475 \pm 125$ B.P. (0-1925; Exploration Department and Geochemical Laboratory, Humble Oil and Refining) This presents an uncorrected date of A.D. 475. Wyckoff (1964) reports a date of $1440 \pm 170$ B.P. (SM-765; Field Research Lab, Socony Mobil Oil Company) from the Satterfield Mounds (34MY88). This yielded an uncorrected age of A.D. 510. Vehik's somewhat later analysis of 34OF39 in Okfuskee County resulted in a radiocarbon date of $1266 \pm 60$ B.P. (Beta-1403). A corrected date reported by Vehik (1980) on this sample was calculated at A.D. 690. All three dates point to an occupation during the middle of the Woodland period. The general age of the burned rock mound features is further collaborated by the recovery of spear point styles that can be comfortably associated with the Woodland period (Ellis, Edgewood, Yarborough, Williams, Marcos, and Lange).

\section{Artifact Content}

A striking characteristic of burned rock mounds is the relative paucity of artifact content. Some of the burned rock features and mound sites excavated by Wyckoff and Barr (1964), Wyckoff, Robinson, and Barr (1963), Schneider (1967), and Vaughn (1975) contain evidence of a hearth and substantial quantities of burned rock, but no culturally modified items. This is also true for Henry's (2008b) more recent work at 34RO351 in Rogers County. Other excavated or test burned rock mounds have yielded only flakes. It should be noted that there are a few exceptions. At least two of the mound sites at Copan Reservoir (34WN55 and 34WN65) studied by Vaughn (1975) have higher densities of spear points, bifaces, and unifaces than corresponding sites at Markham Ferry. Thirty-one sites have received some level of sub-surface investigation (shovel tests, test trenches, or more extensive excavations). This represent roughly a 30 percent sample of the recorded burned rock mound sites. It is unlikely that the paucity of artifact content is a function of sampling error/bias.

Because of the scarcity of artifacts, recovered cultural material from the burned rock features has been enumerated qualitatively rather than quantitatively. This is represented by the number of occurrences of various classes of artifacts present at investigated mound sites (Table 1). As noted above, flakes from tool manufacture and maintenance are the most frequently occurring artifact category found in burned rock mound features, being found at 93 percent (N-29) of the sites. Projectile points are found in 35 percent of the features and include side-notched, corner-notched, and stemmed styles. Grinding slabs/mutates, manos, and nutting stones are also found in 35 percent of the burned rock mounds. The ground stone at Copperhead Mounds appears to be cached or at least discarded in clusters within the mound (Vehik and Pailes 1979). Bedrock mortars occur adjacent to mounds at two sites in Rogers County and probably should be added to the number of sites with ground stone. Bifaces, including drills, double-bitted axes, and gravers are found at 10 sites (32\%) and unifacial tools occur at eight of the 31 investigated sites. Faunal remains are relatively rare - found at only four $(13 \%)$ of the burned rock mound sites. No plant remains were found during excavations at the studied sites, but this absence may be due, in part, to the absence of recovery techniques (e.g, flotation devices) that would have captured charred plant material. Non-utilitarian items such as ornaments or artifacts with social or religious association are limited to a single bone bead from 34OT14. 
Table 1. Qualitative Presence of Artifacts Classes at Burned Rock Mound Site

\begin{tabular}{|l|l|l|}
\hline Artifact Class/Category & Number of Sites Present & Percentage \\
\hline Flakes & 29 & 93 \\
\hline Projectile Points & 11 & 35 \\
\hline Bifaces & 10 & 32 \\
\hline Unifaces & 8 & 26 \\
\hline Ground Stone & 11 & 35 \\
\hline Faunal Remains & 4 & 13 \\
\hline Other (Bone Bead) & 1 & 3.2 \\
\hline
\end{tabular}

The goods recovered during investigation of these sites appear to be unexceptional. None of the chipped or ground tool stone is of exotic origin. It should be noted that no ceramics were recovered from the burned rock mound features, although by the middle Woodland period, some ceramics would have been in use by native societies. There is also a noticeable absence of personal adornment items, the one occurrence being a bone bead found at a mound in Ottawa County.

\section{Function of Burned Rock Mounds}

As discussed earlier, the absence of human remains and goods that can be clearly identified as offerings do not support the mounds being used as markers for the dead. Thus, what was their function? Despite the considerable work on burned rock mounds during the 1960s and 1970s, there was not much deliberation on the purpose of the mounds. It was clearly recognized that the mounds involved food preparation as revealed by the presence of large, prepared, basinshaped hearths and an abundance of burned rock (c.f., Wyckoff and Barr 1964; Vaughn 1975; and Vehik and Pailes 1979). However, the scarcity of plant and animal remains within the hearth areas and the mounds limited further interpretation.

There are some questions that merit attention in relation to the construction of the burned rock mound features. Why create these remarkably unpronounced mounds of burned rock? The large volumes of burned rock that are present could have been more broadly dispersed around the hearth areas, rather than concentrating the rock over the hearth area. It is also intriguing that at least some of the burned rock mounds were constructed on existing natural occurring prairie mounds. It seems as though there is a desire to build or use a mounded surface. Another issue is the selection of landscape settings for the construction of the burned rock mounds and their spatial separation from habitation areas. Most of the mounds are placed on higher terraces, dissected upland ridges, or bluffs overlooking valley systems. This suggests that elevation above the utilized landscape is a factor in placement of burned rock mounds. Perhaps this is to permit the fire from the hearth areas to be more visible to others? None of the research on burned rock mounds speaks of the mounds occurring within the existing boundaries of a habitation site (a camp or village). Why separate the feature from the normal use area of the residential community? Constructed features on the natural landscape, even those as subtle as burned rock mounds, are representative of shared group behavior likely tied to ritual and social identity (c.f. Bender 1993).

The chronological and economic context of burned rock mounds is instrumental to understanding the construction and use of burned rock mounds. In northeastern and north-central Oklahoma they occur during the middle Woodland period. The Woodland is a period of significant change for prehistoric societies. Innovations during the period include increasing sedentism, greater social complexity, widespread use of ceramics, the advent of the bow and arrow, and perhaps most importantly, domestication and harvesting of a suite of indigenous starchy seed plants (chenopodium/ 
amaranth, marsh elder, knotweed, sunflower, may grass, and others; (c.f., Brooks 2013). Cobb and Nassaney (2002) suggest that there was a transformation in human behavior that took place concurrently with plant domestication. This transformation affected perception of the natural world and action in the social world. Here, the landscape was no longer perceived as a natural world to be experienced but also as something that could be created, manipulated, and used. Transformation of the social world not only involved relationships with others (the beginnings of inequality) but also increasing practice of ritual that served to establish relationships with the supernatural, the otherworld.

Ritual feasting served as a mechanism to transmit meaning among the natural, social, and spiritual realms. To separate these ritual practices from the ordinary, daily life, they may have been segregated from the residential locus. This accounts for burned rock mounds' placement away from the village or camp. There may also have been intent to have these feasting locales serve as ritual markers on the landscape. This would explain the purposeful mantling of the burned rock to create mounded surface expressions. The burned rock mounds functioned not only to reinforce relationships with the supernatural but also to maintain a link with the natural landscape.

Feasting was also an important mechanism for defining social relationships and shared ritual practices (Dietler and Hayden 2001; Mills 2004). The absence of a more substantive material content at burned rock mounds hinders defining the nature of the feasting. But, the absence of status/prestige goods, and the presence of domestic items such as chipped and ground stone suggests that potential feasting at burned rock mounds was more tied to communal sharing tethered around group solidarity and perhaps ritual related to food production/acquisition than related to competitive feasting, which served to mark status differentiation.

\section{Concluding Comments}

Burned rock mounds represent an intriguing feature of the cultural landscape during Woodland times. This paper has served to summarize what is currently known about these features and to offer some possible explanations as to how they functioned in these societies. Regrettably, the absence of any extensive work on burned rock mounds since the 1970s seriously hinders interpretation. There remain significant questions to be addressed. Is the absence of plant remains from burned rock mounds a function of recovery bias (no use of flotation devices) or does it reflect that plants are not consumed at these locations? It would also be helpful to better understand the use of off-mound areas. Leith's (2011) study of off-mound areas surrounding Woodland age black midden mounds in southeastern Oklahoma has been highly informative. At black midden mound sites, residential structures are situated off-mound rather than being subsumed in mound construction. Perhaps a similar situation exists for burned rock mounds in northeastern Oklahoma. Clearly, burned rock mounds merit renewed attention to better define their role in Woodland period society.

\section{References Cited}

Allgood, F. P. and Fenton Gray

1974 An Ecological Interpretation for the Small Mounds in Landscapes of Eastern Oklahoma. Journal of Environmental Quality 3:37-41.

Barr, Thomas P.

1965 Archaeological Survey of the Arkansas River Navigational Project, Muskogee and Wagoner Counties, Oklahoma. Oklahoma River Basin Survey, General Survey Report No. 5, Norman.

1966 An Archaeological Survey of the Chimney Rock and Little Saline Reservoirs, Mayes County, Oklahoma. Oklahoma River Basin Survey, General Survey Report No. 8, Norman. 
Bender, Barbara

1993 Landscape, Politics, and Perspective. Berg Press, Oxford.

Branson, Carl

1966 Patterns of Oklahoma Prairie Mounds. Oklahoma Geology Notes 26(11):263-273.

Brighton, Harold

1952 The Archaeological Survey of Keystone Reservoir: A Preliminary Report. Manuscript on file, Oklahoma Archeological Survey, Norman.

Brooks, Robert L.

2013 Implications for Early Agriculture in Northeastern Oklahoma: A Collection of Tools from Lake Hudson, Mayes County, Oklahoma. Oklahoma Archeology (Bulletin of the Oklahoma Anthropological Society) LX: 31-56.

Cain, Robert H.

1974 Pimple Mounds : A New Viewpoint. Ecological Society of America xx: 178-182.

Chapman, Carl H.

1980 Prairie-Forest Potter Traditions: Late Woodland Period. In The Archaeology of Missouri II, by Carl H.Chapman, pp. 78-137. University of Missouri Press, Columbia.

Cobb, Charles R. and Michael S. Nassaney

2002 Domesticating Self and Society in the Woodland Southeast. In The Woodland Southeast, edited by David G. Anderson and Robert C. Mainfort, Jr., pp. 525-539. University of Alabama Press, Tuscaloosa.

Dietler, Michael and Brian Hayden

2001 Feasts: Archaeological and Ethnographic Perspectives on Food, Politics, and Power. Smithsonian Institution Press, Washington D.C.

Drass, Richard R.

1985 Archeological Resources in the Bird Creek Basin: Rogers, Tulsa, and Osage Counties, Oklahoma. Oklahoma Archeological Survey, Archeological Resource Survey Report 21, Norman.

Harden, Patrick

1975 A Survey of the Upper Pryor Creek Watershed. Environmental Assessments, Pauls Valley.

Hawley, Martin F.

2003 The Hawthorne Site (14CT335), A Late Woodland Site in Southeast Kansas. North American Archaeologist 24: 167-193.

Henry, Donald O.

2008a Cultural Resource Survey of Proposed Lipe Mine Extension (ODM Permit \# 4276), Phoenix Coal Company, Rogers County, Oklahoma. Report on file, Oklahoma Archeological Survey, Norman.

2008b Excavation of Stratigraphic Trench, Mound \#1, Lipe Mine Extension (ODM Permit \#4276), Phoenix Coal Company, Rogers County, Oklahoma. Report on file, Oklahoma Archeological Survey, Norman. 
Howard, James H.

1970 Archaeological Investigations at the Weston and Hogshooter Sites, Osage and Washington Counties, Oklahoma. Bulletin of the Oklahoma Anthropological Society 19: 61-100.

Jones, Bruce

1999 Archaeological Overview and Assessment for the Tallgrass Prairie National Preserve, Chase County, Kansas. National Park Service, Midwest Archeological Center, Technical Report No. 61, Lincoln.

Leith, Luther

2011 A Re-conceptualization of the Fourche Maline Culture : the Woodland Period as a Transition in Eastern Oklahoma. Ph.D. dissertation, Department of Anthropology, University of Oklahoma, Norman.

Mills, Barbara J.

2004 Identity, Feasting, and the Archaeology of the Greater Southwest: Proceedings of the 2002 Southwest Symposium. University Press of Colorado, Boulder.

Nichols, Peter et al.

1980 A Survey and Assessment of the Cultural Resources-Oologah Lake Project. Espey, Huston, and Associates, Austin.

Perino, Gregory

1972 Historical Cultural Assessment of the Proposed Skiatook Reservoir, Osage County, Oklahoma. Manuscript on file, Oklahoma Archeological Survey, Norman.

Prewitt, Terry J.

1968 Archaeological Survey of the Oologah Reservoir, Nowata and Rogers Counties, Oklahoma. Oklahoma River Basin Survey, General Survey Report No. 10, Norman.

Rohn, Arthur and Miriam R. Smith

1972 Archaeological Sites of the Copan District, Oklahoma and Kansas. Wichita State University, University Studies No. 91, Wichita.

Schneider, Fred

1967 Eight Archaeological Sites in the Webber's Falls Lock and Dam Area, Oklahoma. Oklahoma River Basin Survey,

Thoburn, Joseph B.

1931 The Prehistoric Cultures of Oklahoma. In Archeology of the Arkansas River Valley, edited by Warren K. Moorehead, pp. 53-82. Yale University Press, New Haven.

Vaughn, Sheila

1975 Archaeological Investigations for the Copan Reservoir, Northeast Oklahoma and Southeast Kansas. Oklahoma River Basin Survey, Archaeological Site Report No. 29, Norman.

Vehik, Rain

1980 Archaeological Test Excavations of Two Burned Rock Mounds (34OF-38 and 34OF-39) in Okfuskee County, Oklahoma. Archaeological Research and Management Center, Projecxt Report Series No. 6, Norman. 
Vehik, Susan and Richard Pailes

1979 Copan: Excavations in the Copan Reservoir of Northeastern Oklahoma and Southeastern Kansas. Archaeological Research and Management Center, Research Series Number 4, Norman.

Wallis, Charles S.

1979 Letter to Clifford Moss, USDA Soil Conservation Service State Office, Stillwater, summarizing status of the survey of Impoundment B-2, Okfuskee County Tributaries Watershed. Letter on file, Oklahoma Archeological Survey, Norman.

Wenner, David J.

1947a Preliminary Appraisal of the Archaeological Resources of the Fort Gibson Reservoir. Manuscript on file, Oklahoma Archeological Survey, Norman.

1947b Preliminary Appraisal of the Archaeological Resources of Tenkiller Ferry Reservoir. Manuscript on file, Oklahoma Archeological Survey, Norman.

1948 Preliminary Appraisal of the Archaeological Resources of the Eufaula Reservoir (Onapa and Canadian Reservoir Areas). Manuscript on file, Oklahoma Archeological Survey, Norman.

William, Barry G.

1988 14CT347: A Burned Rock Complex of Southeastern Kansas. Kansas State Historical Society, Archeological Department Series \#1, Topeka.

Wyckoff, Don G.

1964 Two Radiocarbon Dates from the Markham Ferry Reservoir Archaeology. Oklahoma Anthropological Society Newsletter 12(8)2-3.

Wyckoff, Don G. Philip Robinson, and Thomas G. Barr

1963 Markham Ferry Reservoir Archaeological Resources, Mayes County, Oklahoma. Oklahoma River Basin Survey, General Survey Report No. 1, Norman.

Wyckoff, Don G. and Thomas P. Barr

19641963 Archaeological Activities in the Markham Ferry Reservoir Area, Mayes County, Oklahoma. Oklahoma River Basin Survey, General Survey Report No. 4, Norman. 